\title{
PENGARUH DISPLAY PRODUK PADA KEPUTUSAN PEMBELIAN KONSUMEN
}

\author{
Ina Melati \\ Management Department, School of Business Management, BINUS University \\ Jl K.H. Syahdan No 9, Palmerah, Jakarta Barat 11480 \\ ina.melati.ind@gmail.com
}

\begin{abstract}
Most of ritel outlet recently using product display as a one of their best marketing strategy, the reason is quiet easy to be understood, since consumers are too easy to be teased by those kind of beautiful product display that is being displayed by the retail outlet. The good retail outlets are trying their best to design and make the very good product display, so they can attract more consumers and make them not thinking twice to visit their store and purchase lots of thing. Clearly seeing that an attractive product design is able to influence a consumer to make a buying decision.
\end{abstract}

Keywords: product display and buying decision product

\begin{abstract}
ABSTRAK
Sebagian besar perusahaan ritel saat ini menggunakan display produk sebagai salah satu strategi pemasaran andalannya, alasannya cukup mudah dimengerti, karena saat ini konsumen begitu mudahnya tergoda oleh tampilan display pada sebuah toko ritel. Pengusaha ritel yang jeli berlomba - lomba untuk mendesain dan mewujudkan sebuah display produk yang bisa membuat pengnjung tidak berpikir dua kali untuk masuk ke dalam toko mereka. jelas terlihat bahwa sebuah display produk ternyata mampu mempengaruhi konsumen dalam mengambil keputusan dalam melakukan pembelian
\end{abstract}

Kata kunci: display produk dan proses pengambilan keputusan konsumen 


\section{PENDAHULUAN}

Tidak dipungkiri lagi, dunia masa kini dipenuhi dengan orang - orang yang memiliki ide - ide cemerlang, ide - ide yang sangat menarik, namun juga sangat unik. Semua orang berlomba untuk membuat sebuah produk yang lain daripada yang lain, yang hanya ada sedikit di dunia dan hanya beberapa orang saja yang bisa memilikinya.

Salah satu yang perkembangannya sangat cepat adalah dunia fashion, beberapa negara di dunia seperti Amerika, Italy, Prancis, Jepang dan yang sekarang sedang sangat digandrungi oleh banyak sekali orang di seluruh dunia adalah selera fashion dari Korea.

Perancang - perancang muda adalah salah satu pihak yang melahirkan beragam rancangan rancangan dan item - item fashion yang unik - unik tersebut, dari mereka banyak terlahir dan tercetus ide - ide menarik seputar dunia fashion, bukan hanya dari segi rancangan fashionnya itu sendiri tapi juga hal - hal yang melingkupi dunia fashion itu sendiri.

Mereka mengungkapkan bahwa dunia fashion adalah sebuah dunia yang "unique,creative,very dynamic but complicated" ,di dunia fashion, mereka tidak hanya diharuskan untuk membuat sebuah rancangan busana yang indah dan menarik, tetapi juga harus bisa mengikuti selera konsumen dan bisa dijual di pasar. Mereka dituntut untuk membuat sebuah strategi -strategi yang bisa membuat rancangan busana mereka dan mereka sendiri di kenal oleh masyarakat luas.

Oleh sebab itu, salah satu hal yang penting mereka lakukan ketika memiliki sebuah rancangan baru, adalah menggelar sebuah pagelaran busana atau yang lebih dikenal sebagai "fashion show". Disinilah ajang mereka untuk memamerkan "brand" dan ide - idenya, Mereka harus bekerja extra keras dan "all out" ketika mereka akan menggelar pagelaran busana, karena pada saat inilah kesempatan mereka untuk menjual produk mereka, Bagaimanapun caranya mereka harus membuat sebuah pagelaran yang spektakuler dan hebat, sesuai dengan konsep dan tema rancangan busana yang mereka buat, Sebagian besar perancang busana terkenal seringkali menggunakan supermodel catwalk tingkat dunia yang memiliki tubuh indah semampai yang sempurna, sehingga baju rancangan mereka akan semakin terlihat indah dan menawan, dan memiliki nilai jual yang jauh lebih tinggi.

Seiring dengan perkembangan mode yang kian melesat ini, membuat banyak pebisnis di dunia melihat adanya peluang bisnis yang bisa mereka gali, selanjutnya yang terjadi adalah konsumen kembali dimanjakan oleh mulai tumbuh dan menjamurnya bisnis retail yang menjual beragam jenis pakaian dan item fashion untuk beragam segmentasi dan target pasar.

Senada dengan pagelaran busana, retail menjadi sebuah lumbung padi baru bagi para perancang, dimana bisnis retail menjadi jembatan antara mereka dengan konsumen, karena toko retail menjadi tempat bagi para konsumen yang suka berburu baju rancangan terbaru. Harga yang ditawarkan pun bervariatif, baju - baju dengan brand terkemuka dan hasil rancangan perancang busana dunia memang dijual dengan harga yang sangat mahal, tetapi kini ada lebih banyak lagi toko retail yang menjual produk dengan harga yang lumayan mudah dijangkau oleh kantong konsumen. Toko ritel menjadi demikian menariknya sekarang, karena mereka seringkali membuat strategi strategi pemasaran yang unik untuk membuat konsumen kembali datang berkunjung, sekedar melihat - lihat, kemudian ada yang melakukan pembelian dan yang lebih banyak lagi terjadi adalah mereka kembali datang, dan kembali melakukan pembelian secara berulang - ulang dan terus menerus, alasannya mudah sekali dikenali, karena setiap saat ada saja model terbaru yang di "launching" di pasar, Namun bukan hanya mengikuti trend saja tetapi toko ritel juga memperhatikan kebutuhan konsumennya, misalnya saja berkaitan dengan musim, bagi sebagian besar negara - negara yang 
mengalami 4 musim, maka secara otomatis perancang busana dan tentu saja toko ritel akan menyesuaikan produknya sesuai dengan musim yang sedang dan akan terjadi.

Beberapa strategi yang mereka lakukan adalah memberikan potongan harga pada koleksi musim panas ketika musim panas berahir , atau mulai menampilkan koleksi musim dingin di awal awal bulan Agustu, Atau dengan mendesain lay out toko yang sedemikian rupa sehingga memberikan kenyaman bagi para konsumen untuk berbelanja, bahkan beberapa toko ritel membuat lay-out toko persis seperti rumah atau kamar, sehingga membuat konsumen merasa nyaman untuk mencoba - coba dan mencocok - cocokkan busana dengan pernak - pernik selayaknya dirumah atau kamar mereka sendiri.

Strategi menarik lainnya adalah dengan menampilkan display produk-produk mereka, Toko ritel sekarang tidak lagi hanya sekedar "menaruh" produk mereka dan disusun secara horizontal atau vertikal berjajar di depan etalase toko mereka, atau dengan menggunakan boneka manekin dengan wajah manusia yang serius dan berdiri tegak lurus, Namun kini display produk di toko ritel menjadi teramat sangat menarik, beragam produk ditata secara asimetris ditambah dengan elemen - elemen tertentu, detail - detail dan pernak - pernik yang serasi dan menunjang rancangan, sehingga menarik perhatian dan minat konsumen yang berlalu lalang di depan toko ritel mereka, yang unik dan menarik adalah, ketika ditanyakan pada beberapa konsumen yang lewat di depan etalase toko ritel mengenai penyebab utama mereka mampir dan akhirnya berbelanja di toko ritel tersebut, sebagian besar menjawab pada awalnya mereka hanya sekedar melintas di depan toko,dan sama sekali tidak bertujuan untuk membeli apapun di toko tersebut, tetapi selanjutnya mereka menambahkan, display toko di etalaselah yang seakan - akan melambai -lambaikan tangannya kepada mereka seolah memanggil untuk mampir masuk ke dalam toko, skaligus menggoda untuk membeli.

Itulah mengapa pada akhirnya sebuah display produk menjadi sebuah urusan yang penting bagi kelangsungan sebuah toko ritel, bahkan banyak sekali toko ritel yang rela mengeluarkan ratusan juta rupiah untuk menyewa ahli pembuat display produk untuk mempercantik etalase toko ritelnya dan menggantinya setiap kali mereka mengeluarkan koleksi terbaru atau disesuaikan dengan trend dan musim pada saat itu.

Seperti sudah diketahui bersama, bahwa Indonesia memiliki jumlah penduduk terbesar keempat di dunia, sehingga menjadikannya sebagai salah satu pasar terbesar di dunia, apalagi ditambah dengan gaya hidup konsumtif sebagian besar masyarakatnya khususnya yang tinggal di kota - kota besar, membuat banyak sekali perusahaan - perusahaan besar di seluruh dunia mencoba peruntunganya di Indonesia, tidak terkecuali perusahaan ritel.

\section{PEMBAHASAN}

\section{Prilaku Konsumen}

Prilaku konsumen adalah sebuah prilaku dari seorang atau sekelompok pembeli, ketika mereka membeli sebuah produk atau jasa menurut Kotler\&Armstrong (2006), Ada banyak hal yang meliputi prilaku pembelian seorang atau sekelompok pembeli, mulai dari apa sajakah karakteristik yang mempengaruhi mereka dalam melakukan pembelian, prosesnya ketika mereka memutuskan untuk membeli sebuah barang, hingga seperti apakah prilaku konsumen pada tiap - tiap negara.

Karakteristik yang mempengaruhi mereka dalam melakukan pembelian adalah salah satu hal yang sangat penting di ketahui oleh pemasar ketika mereka akan menjual produk, karena pada tujuannya mereka ingin produk mereka laku keras, untuk tujuan tersebut mereka harus paham betul siapa calon konsumennya, dan lebih lanjut lagi apa yang sebenarnya mempengaruhi mereka untuk 
membeli sebuah produk, apa sebenernya yang mereka butuhkan dan inginkan, berangkat dari situlah pemasar dapat memberikan masukan pada produsen tetang bagaimanakah produk yang nantinya akan disukai oleh pasar.

Ada beberapa karakteristik yang mempengaruhi konsumen dalam melakukan pembelian, yaitu : (a) Faktor Budaya; (b) Faktor Sosial; (c) Faktor Personal, dan (d) Faktor Psikologis

Dari beberapa karakteristik yang memepengaruhi konsumen dalam melakukan pembelian diatas , yang sangat menarik diperbincangkan saat ini adalah faktor personal dan faktor psikologis, lebih dalam lagi membahas mengenai faktor personal ada beberapa karakteristik yang mempengaruhi konsumen dalam melakukan pembelian, yaitu : (a) Age and Life-Cycle Stage; (b) Occupation; (c) Economic Situation, dan (d)Lifestyle.

Konsumen di Indonesia, khususnya di Jakarta pada masa kini adalah konsumen yang sangat meperhatikan lifestyle, sehingga ketika mereka ingin melakukan sebuah pembelian semuanya kemudian dipengaruhi oleh lifestyle masing - masing individu, contoh yang paling menarik saat ini adalah lifestyle sebagian besar warga di kota - kota besar di Indonesia khusnya Jakarta yang senang sekali menghabiskan waktu di mal - mal yang bisa dikatakan sangat mudah sekali dijumpai di Jakarta saat ini, apalagi jika akhir pekan datang, sepertinya semua warga Jakarta membanjiri mal-mal tersebut dengan beragam tujuan, ada yang sekedar jalan - jalan, melihat - lihat, survey produk tertentu, makan bersama keluarga, menonton bioskop dan tentu saja berbelanja, ada yang memang dari awalnya sudah berniat untuk membeli sebuah produk ada yang karena hanya "tergiur"saja sehingga memutuskan untuk membeli sebuah produk, atau yang biasa disebut sebagai "Impulsive Buying" atau individunya biasa dikenal sebagai "Impulsive Buyer", sedikit mengulas tentang "Impulsive Buying Behaviour" yang semakin sering menjangkiti sebagian besar masyarakat yang tinggal di kota - kota besar, dimana "Impulsive Buying Behaviour" adalah sebuah perilaku konsumen yang seringkali secara tiba - tiba terpengaruh oleh seautu hal sehingga mereka pada akhirnya memutuskan untuk membeli sebuah produk, meskipun sebenarnya mereka tidak terlalu memerlukan produk tersebut, keputusan mereka membeli produk tersebut lebih disebabkan karena pengaruh lingkungan sekitar, seperti pengaruh teman yang sedang pergi bersama mereka, adanya iklan - iklan diskon yang sudah menyambut mereka di lobby pintu masuk pusat perbelanjaan, atau tentu saja display produk yang mereka buat di etalase depan toko.

Sementara itu faktor - faktor psikologis yang mempengaruhi konsumen dalam melakukan sebuah pembelian adalah : Motivation, Perception, Learning, Beliefs dan Attitude.

Mengapa faktor psikologis menjadi salah satu faktor yang juga sangat menarik diperbincangkan saat ini, adalah adanya faktor beliefs dan attitude di dalamnya yang bisa dikaitkan dengan lifestyle "impulsive buying' pada faktor personal diatas. Dimana beliefs dan attitude seorang pembeli mengacu pada keyakinan orang untuk membeli sebuah produk karena adanya sebuah kepercayaan di dalam dirinya bahwa dia harus membeli produk tersebut, selanjutnya atitude berbicara mengenai bagaimana pandangan atau sikap seorang konsumen terhadap sebuah produk atau jasa, jika dia melihat sebuah produk atau jasa itu sebagai sebuah produk yang bermutu dan memiliki nilai tambah, maka dengan dilandasi juga dengan faktor personal dan beberapa faktor lainnya maka konsumen akan memutuskan untuk membeli produk tersebut mnurut Kotler \& Armstrong (2006)

\section{Proses Pengambilan Keputusan Konsumen dalam Melakukan Pembelian}

Proses pembelian konsumen menjadi suatu hal lain yang penting diketahui oleh pemasar, karena dari situlah pemasar akan mengetahui kegiatan - kegiatan apa saja yang dilakukan seorang pembeli sebelum dan sesudah dia membeli sebuah produk atau jasa. 
Sehingga dari sana akan diperoleh berbagai macam informasi dan masukan tentang apa sajakah yang harus mereka lakukan agar supaya konsumen membeli produk mereka dan lebih lanjut adalah membeli kembali dan yang menjadi tujuan utama adalah menjadikan konusmen sebagai pelanggan tetap mereka.

Menurut Hawkins, Mothersbaugh \& Best (2007) ada beberapa tahapan yang dilalui konsumen ketika mereka akan membeli sebuah produk atau jasa, yaitu :

- Need recognition: Tahap dimana konsumen merasakan adanya kebutuhan atau keinginan terhadap sebuah produk atau jasa.

- Information Seach: setelah mereka menyadari akan adanya sebuah kebutuhan atau keinginan biasanya mereka akan mulai mencari informasi-informasi dan alternatif-alternatif mengenai produk atau jasa tersebut.

- Evaluation of Alternatives: Jika sudah mengumpulkan banyak informasi, biasanya mereka akan mulai memilah - milah mana saja produk yang menurut mereka bisa dijadikan sebagai pilihan atau alternatif, sehingga akan mudah bagi mereka untuk mengambil keputusan priduk atau jasa manakah yang ingin mereka pilih

Hal yang selanjutnya perlu diperhatikan oleh pemasar adalah adanya situasai tertentu dan aktivitas pemasaran yang akan mempengaruhi dan menentukan prilaku konsumen dalam melakukan sebuah pembelian.

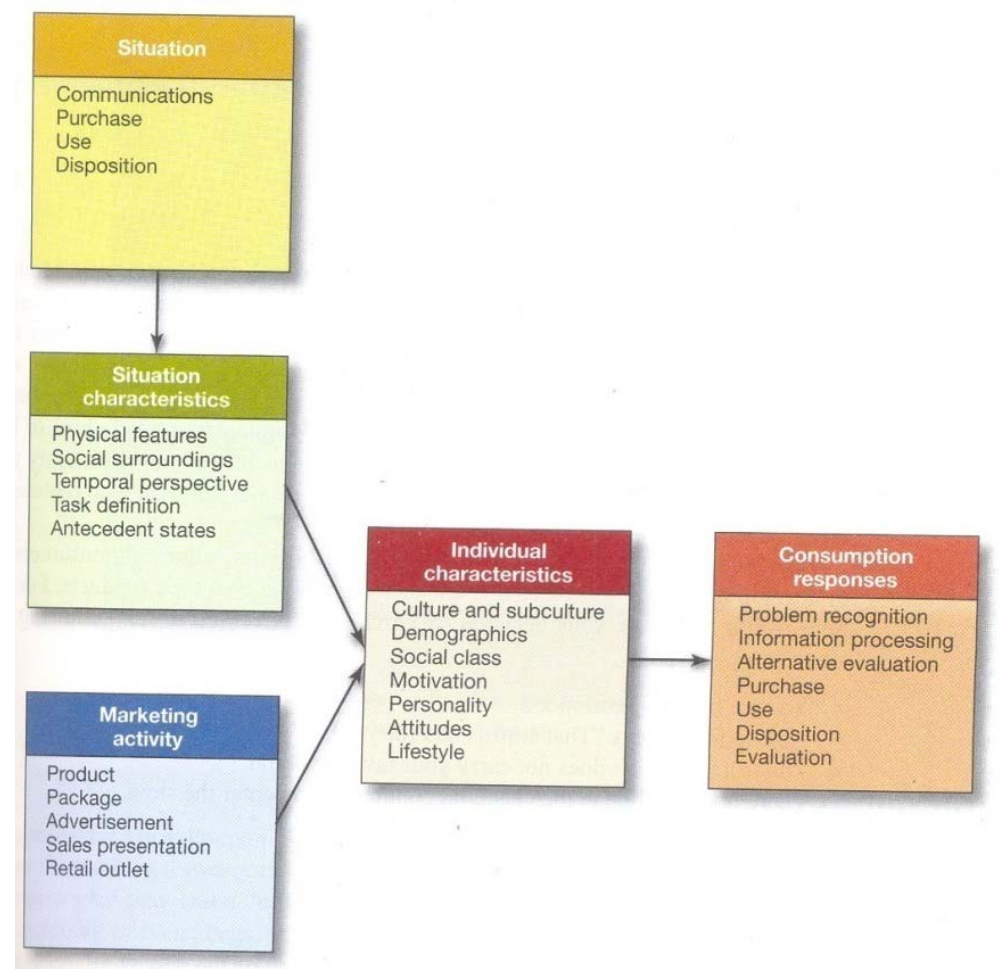


Seperti yang terlihat dalam bagan yang dibuat oleh Hawkins, Mothersbaugh \& Best ((2007) dibawah ini:

Dari bagan diatas terlihat beberapa aktivitas pemasaran yang mempengaruhi konsumen dalam mengambil keputusan pembelian, diantaranya adalah: kebutuhan akan produk yang bermutu, packaging yang "eye-cacthing", pengiklanan yang menarik, presentasi yang mudah dimengerti, pemasaran dan distribusi melalui retail outlet. Retail outlet saat ini tampaknya menyadari betul tentang hal ini, sehingga kemudian mereka membanjiri pasar dengan beragam jenis strategi pemasaran, untuk menarik konsumen sebanyak - banyaknya, salah satunya dengan cara mendesain sebuah display produk yang menarik minat konsumen, dan membuat sebuah produk memiliki nilai tambah dan nilai jual yang tinggi. Sebuah retail outlet harus bisa memikirkan dan membuat sebuah display yang tidak saja terlihat menarik, dan membuat pengunjung yang melintas menoleh dan berhenti didepan tokonya, tetapi kemudian masuk ke dalam, dan pada akhirnya berbelanja disana.

\section{Display}

Display produk adalah sebuah aktivitas untuk memamerkan sebuah produk supaya terlihat atraktif, mudah dilihat dan menarik minat pengungjung (about.com, 2012). Sebuah display produk didukung oleh beragam jenis elemen seperti warna, cahaya, bau, suara, bahkan digital teknologi yang kesemua itu diharapkan bisa mempengaruhi konsumen untuk membeli produk - produk yang di jual di sebuah toko. Display produk adalah salah satu "tools" untuk memperkenalkan image dari brand perusahaan tersebut dan seringkali membantu perusahaan untuk menggambarkan produk seperti apa yang mereka jual dan tentu saja untuk lebih menegaskan brand mereka kepada target konsumen yang mereka sasar.

Sementara itu menurut Clow \& Baack (2010) display produk adalah sebuah strategi pemasaran yang sangat efektif bagi sebuah industry ritel, khususnya produk fashion, dimana perusahaan melihat semakin banyaknya fenomena "Impulsive Buying" di kalangan masyarakat, dan disadari atau tidak salah satu penyebabnya adalah: sebuah desain display produk yang indah, menarik dan menggoda”.

\section{PENUTUP}

Saat ini hampir seluruh retail outlet berlomba - lomba membuat sebuah display produk yang sangat menarik, bagaimana tidak, hanya dengan melihat sebuah display produk saja seorang konsumen yang tadinya tidak berminat untuk membeli apapun, bisa saja kembali pulang kerumah dengan membawa sepuluh kantong belanjaan yang terisi penuh.

Sebuah desain display produk yang menarik menurut Hawkins, Mothersbaugh \& Best (2007) harus mencakup beberapa hal dibawah ini:

- Display produk harus disesuaikan dengan produk dan target konsumen yang ingin disasar.

- Warna adalah salah satu elemen yang sangat menentukan dalam mebuat sebuah display akan terlihat sangat menarik, apalagi jika warna yang dipilih adalah warna - warna cerah, Namun pemilihan warna cerah juga harus hati - hati dan disesuaikan, tidak serta merta untuk menghadirkan kesan menarik, display menjadi dipenuhi dengan beraneka macam warna cerah yang tentu saja akan mengesankan tampilan display toko anak - anak, sementara yang dijual adalah produk untuk dewasa, tetapi kembali lagi pemilihan warna harus disesuaikan dengan produk apa yang akan dijual, siapa targetnya, dan tentu saja seperti apa trend yang sedang "in" saat ini, trend yang dimaksud misalnya berkaitan dengan musim, atau berkaitan dengan fenomena dan isu - isu yang sedang hangat di perbincangkan oleh khalayak ramai, bisa juga berkaitan 
dengan hobi tertentu yang sedang digandrungi oleh sebagian besar masyarkat pada masa kini, dan lain sebagainya.

- Display produk yang dilengkapi dengan informasi tertulis didalamnya akan membuatnya jauh lebih menarik perhatian konsumen, misalnya dengan adanya sedikit cerita mengenai produk tersebut, bisa juga dengan adanya informasi harga dari setiap item yang dipajang.

- Penggunaan teknologi canggih, seperti misalnya "running text" dalam bentuk elektronik, atau dalam contoh retail outlet untuk produk elektronik, adanya produk - produk yang menunjang yang memungkinkan pengunjung untuk mencoba produk tersebut secara langsung, juga merupakan sarana penunjang dalam membuat display produk menjadi lebih menarik minat konsumen

- Cahaya adalah elemen penting lainnya dalam sebuah desain display produk, cahaya yang memadai bukan hanya sekedar terang tapi menyilaukan mata, tetapi cahaya yang bisa menonjolkan kelebihan dan nilai tambah dari produk yang di pajang.

Pada akhirnya dapat disimpulkan bahwa sebuah display produk yang menarik, adalah merupakan sebuah strategi pemasaran yang sangat ampuh saat ini, terlebih bagi perusahaan retail. Display produk ternyata mampu mempengaruhi konsumen dalam melakukan pembelian, terbukti dengan semakin banyaknya "Impulsive Buyer". Selanjutnya apabila diteliti lebih lanjut bisa saja prilaku "Impulsive Buying” menjadi sebuah prilaku yang akan sangat diminati oleh pemasar dan pengusaha ritel, mengapa? karena "Impulsive Buying" akan memotong hampir sebagian besar proses pengambilan keputusan konsumen dalam melakukan pembelian.

Dengan adanya display yang menarik, pengusaha ritel dan pemasar mengharapkan konsumen tidak perlu lagi melalui tahap mencari informasi-informasi dan alternatifnya kemudian mengevaluasi alternatif-alternatif tersebut yang mungkin saja awalnya sudah berniat untuk membeli produk mereka, tetapi karena adanya informasi dan alternative lain yang lebih baik, sehingga konsumen memutuskan untuk membeli produk tersebut, harapan pengusaha ritel dan pemasar adalah konsumen melewati toko mereka, melihat display pada etalasenya, menjadi sangat tergoda karenanya, memutuskan masuk ke dalam toko dan keluar dengan belasan kantong belanja.

\section{DAFTAR PUSTAKA}

Clow,K and Baack,D (2010). Integrated Advertising, Promotion, and Marketing Communications, Prentice Hall, New Jersey

Hawkins,Mothersbaugh and Best (2007) Consumer Behaviour, Mc Graw Hill, New York

Kotler,P and Armstrong,G (2006). Priciples of Marketing, Eleventh Edition, Prentice Hall, New Jersey.

http://retailindustry.about.com/od/glossary/g/visualmerchandi.htm 